\title{
Two-level septocolumellar suture technique in closed septorhinoplasty
}

\author{
Kapalı septorinoplastide iki seviyeli septokolumellar sütür tekniğgi
}

\author{
Nevzat Demirbilek (1), Cenk Evren (1)
}

Department of Otolaryngology, Medilife Beylikdüzü Hospital, İstanbul, Turkey

\begin{abstract}
Objectives: This study aims to investigate the effect of two-level septocolumellar suture technique on closed septorhinoplasty.

Patients and Methods: Between January 2016 and June 2017, a total of 45 patients (28 females, 17 males; mean age $29.2 \pm 10.3$ years; range, 18 to 55 years) who underwent closed septorhinoplasty with no strut graft use using twolevel septocolumellar suture technique were included. The absorbable 4.0 Vicryl suture was used as the suture material. The visual analog scale (VAS) was used to grade nasal obstruction preoperatively and at six months after surgery.

Results: Postoperative redeviation not leading to passage blockage and any aesthetic defect was observed in one patient. No major or minor functional and aesthetic deformity was observed in any of the patients. The mean pre- and postoperative VAS scores were $7.3 \pm 1.7$ and $1.6 \pm 1.9$, respectively $(\mathrm{p}<0.0001)$.

Conclusion: Our study results suggest that two-level septocolumellar suture technique is very effective in keeping the septum in the midline easily in cases with closed septorhinoplasty, and it provides nasal tip support and does not disrupt symmetry of the alar base.
\end{abstract}

Keywords: Redeviation, septocolumellar suture, septorhinoplasty.

The nose, which is located in the middle of the face, is of vital importance, as it constitutes both the facial aesthetic focal point and the beginning of the respiratory system. As Tardy rightly put it "wherever the septum goes, there goes the nose", positioning of the
$\ddot{O} Z$

Amaç: Bu çalışmada iki seviyeli septokolumellar sütür tekniğinin kapalı septorinoplasti üzerine etkisi araştırıldı.

Hastalar ve Yöntemler: Ocak 2016 - Haziran 2017 tarihleri arasında, iki seviyeli septokolumellar sütür tekniği kullanılarak strut greft kullanılmaksızın kapalı septorinoplasti yapılan toplam 45 hasta (28 kadın, 17 erkek; ort. yaş $29.2 \pm 10.3$ yıl; dağılım, 18-55 yıl) çalışmaya alındı. Sütür materyali olarak emilebilir 4.0 Vicryl sütür kullanıldı. Ameliyat öncesi ve ameliyat sonrası 6 . ayda burun tıkanıklığını derecelendirmek için görsel analog ölçeği (GAÖ) kullanıldı.

Bulgular: Bir hastada burun tıkanıklığına ve estetik deformiteye neden olmayan ameliyat sonrası redeviasyon görüldü. Hastaların hiçbirinde majör veya minör fonksiyonel ve estetik deformite gözlenmedi. Ameliyat öncesi ve sonrası GAÖ skoru, sırasiyla $7.3 \pm 1.7$ ve $1.6 \pm 1.9$ idi $(\mathrm{p}<0.0001)$.

Sonuç: Çalışma bulgularımız iki seviyeli septokolumellar tekniğin, kapalı septorinoplasti yapılan olgularda septumun orta hatta kolayca tutulmasında çok etkili olduğunu ve burun ucu desteği sağladığını ve alar tabanının simetrisini bozmadığını göstermektedir.

Anahtar sözcükler: Redeviasyon, septokolumellar sütür, septorinoplasti.

septum in the midline is important both aesthetically and functionally. When a line is drawn from the rhinion to the nasal spine, the cartilage which remains in front of the line is what provides the essential structural support for the nasal septum. ${ }^{[1,2]}$ In curved noses, functional and

Received: August 14, 2018 Accepted: November 29, 2018 Published online: March 28, 2019

Correspondence: Cenk Evren, MD. Medilife Beylikdüzü Hastanesi, Kulak Burun Boğaz Kliniği, 34524 Beylikdüzü, İstanbul, Turkey. e-mail: drcenkevren@yahoo.com 
aesthetic success would be achieved in many cases, if the septum is corrected and approximated in the midline preserving the nasal support. ${ }^{[3]}$

This region is the origin of surgical failure or recurrence. ${ }^{[4]}$ The septum is not considered sufficient during nasal spine fixation surgeries, since the connection between the septum and nasal spine is damaged, resulting in septal laxation, which may lead to postoperative external deviation in the nasal pyramid. Furthermore, inadequacy of tip support prepares the basis for supratip development to the tip ptosis. Measures taken to reduce tip projection may also lead to the loss of tip projection, columellar retraction, and supratip depression. ${ }^{[5]}$

In addition to classical septoplasty techniques used during septorhinoplasty to correct the septum and to stabilize the nasal tip support, such as cartilage scoring and cartilaginous premaxillary suturing, various suture techniques have been applied including the lateral crural steal techniques, medial crural-caudal septal imbrications, medialization of the medial crural footplates, shield type or strut grafts. ${ }^{[3-11]}$ Most surgeons use a combination of these techniques for the stabilization of nasal tip support.

In the present study, we aimed to investigate the effect of two-level septocolumellar suture technique on closed septorhinoplasty and to present our long-term results in the light of literature data.

\section{PATIENTS AND METHODS}

Between January 2016 and June 2017, a total of 45 patients ( 28 females, 17 males; mean age $29.2 \pm 10.3$ years; range, 18 to 55 years) who underwent closed septorhinoplasty with no strut graft use using two-level septocolumellar suture technique at the ear, nose, and throat department of Medilife Beylikdüzü Hospital, Istanbul, Turkey were included. Patients who underwent open septorhinoplasty, or revision rhinoplasty, those who were subjected to techniques with strut grafts during surgery, and those who had postoperative major trauma were excluded from the study. A written informed consent was obtained from each patient. The study protocol was approved by the Bakırköy Dr. Sadi Konuk Training and Research Hospital Ethics Committee (2016/130). The study was conducted in accordance with the principles of the Declaration of Helsinki.

All patients were scheduled for routine followup at one and six months, and every six months thereafter. The patients were preoperatively and early postoperatively (at six months) photographed. Anterior rhinoscopy was used to examine the inner part of the nose. Cosmetic findings and subjective complaints such as asymmetry of the nasal tip region, contour abnormalities, axis inclination, and skin thinning were recorded. Each patient used a $10-\mathrm{cm}$ visual analog scale (VAS) to grade general nasal obstruction preoperatively and at six months after surgery. All patients were asked to quantify subjective nasal obstruction using the VAS from 0 (no obstruction) to 10 (complete obstruction). The VAS scores were measured and recorded manually.

Routine preoperative and pre-anesthesia examinations were carried out. All patients underwent surgery under general anesthesia. The surgical procedure was performed by a single surgeon in all patients. After applying $0.05 \%$ of oxymetazoline hydrochloride to the nasal mucosa, lidocaine and 1/100.000 of adrenaline were infiltrated.

A unilateral hemi-transfixion incision to the anterior portion of the nasal septum was performed. This incision was combined with intercartilaginous incision. The dissection was made in the subperichondrial and subperiosteal regions right to the nasal radix, maintaining upper lateral cartilages and dorsal bone exposition. Subsequently, both septal mucoperichondrial flaps were elevated and an appropriate technique for septal pathology was applied. L-strut was preserved to maintain the structural function of the septum. The anterior septum was freed from all mucosal connections. Deviations of the maxillary crest were corrected by excision or medial replacement. Of note, excess cartilage in the caudal septal base was resected. Other techniques including scoring, triangular cartilage resection or shifting the caudal septum to the opposite side of dislocation were carried out. Lateral hump resection and medial osteotomies were performed to correct external deformities following septoplasty. Septocolumellar sutures were, then, used.

The septum was initially reattached to the maxillary spine through a 4.0 absorbable monofilament suture (Vicryl, Ethicon Inc., Somerville, NJ, USA). A tunnel between the medial crus of the lower lateral cartilages was created with angled converse scissors or curved iris scissors. The cartilage was, then, prepared for superior septocolumellar suture with a 4.0 absorbable monofilament suture (Vicryl, Ethicon Inc., Somerville, NJ, USA). The first suture was placed superiorly. The needle was first passed through cauda of the incision side from lateral to medial $3-\mathrm{mm}$ anterior to the mucoperichondrial incision (Figure 1a). The needle was advanced through the septal cartilage (Figure 1b). The needle was passed through the non-deviated, nonincised side mucoperichondrium from medial to lateral (Figure 1c). Full-thickness was reinforced 2-mm posterior of the mucoperichondrial incision, the needle 


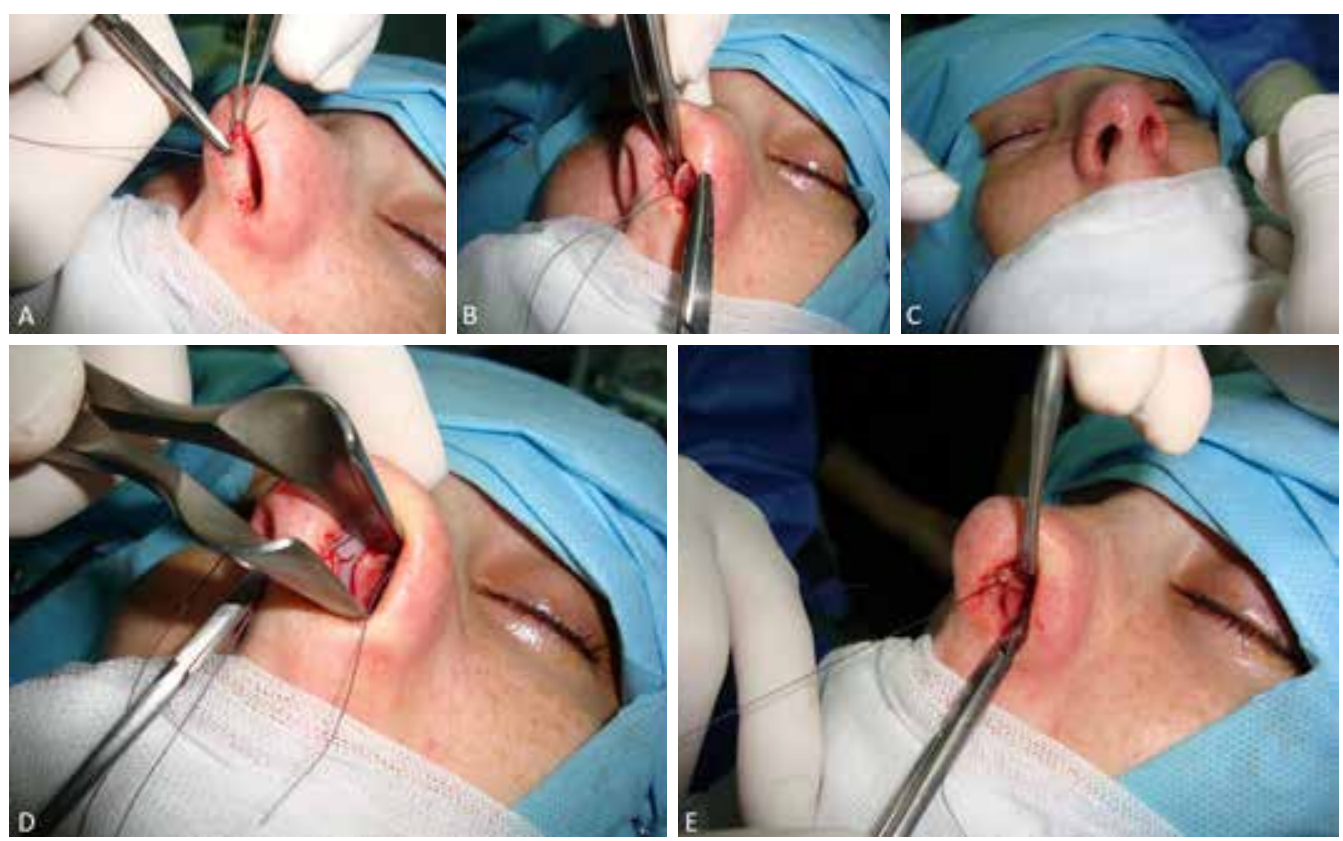

Figure 1. Sequences of superior septocolumellar suture.

was removed at the contra-mucoperichondrium and it was, then, tied (Figures $1 \mathrm{~d}$ and e).

Inferior septocolumellar suturing was performed with a 4.0 absorbable monofilament suture (Vicryl, Ethicon Inc., Somerville, NJ, USA). The needle was first passed through the medial crus of lower lateral cartilage of incision side from lateral to medial 3-mm anterior to the mucoperichondrial incision (Figure 2a). The needle was advanced through the septal cartilage (Figure 2b). The needle was passed through non-deviated, nonincised side mucoperichondrium from medial to lateral (Figure 2c). Full-thickness was reinforced 2-mm
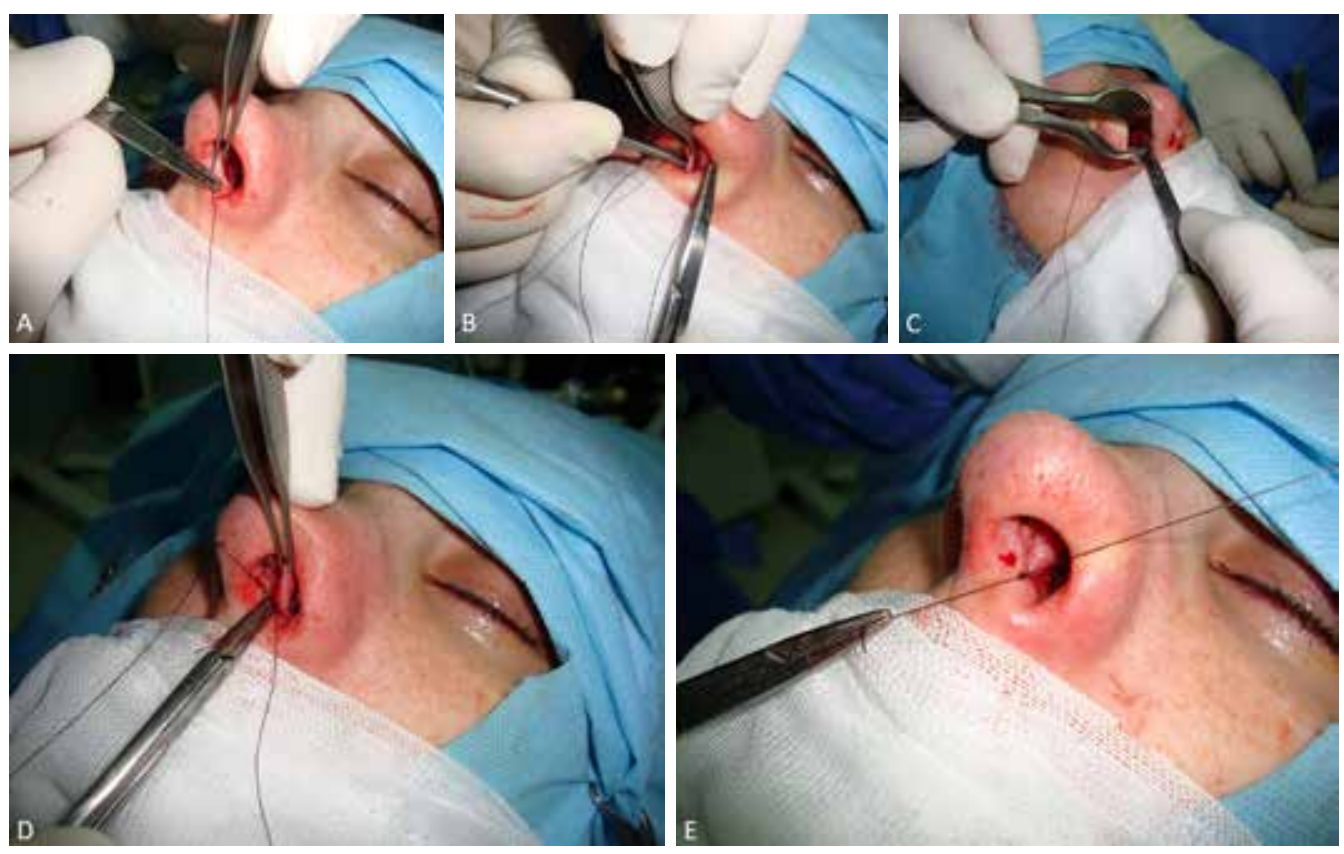

Figure 2. Sequences of inferior septocolumellar suture. 

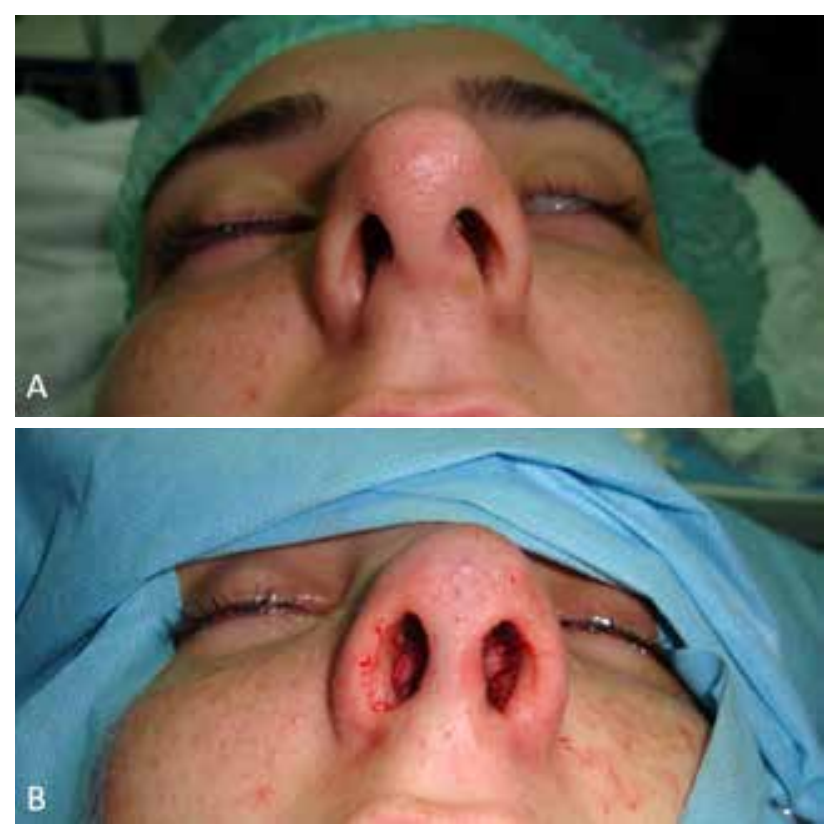

Figure 3. Pre- and postoperative images.

posterior of the mucoperichondrial incision, the needle was removed at the contra-mucoperichondrium and it was, then, tied (Figures $2 \mathrm{~d}$ and e).

The internal Doyle silicon splints were left in place for two days in all patients. The external splints were removed between the days 7 and 10 and fixed with micropore plaster for a period of one week. Pre(Figure $3 \mathrm{a}$ ) and postoperative (Figure $3 \mathrm{~b}$ ) images of a patient operated with two-level septocolumellar suture technique are shown.

\section{Statistical analysis}

Statistical analysis was performed using the IBM SPSS for Windows version 21.0 (IBM Corp., Armonk, NY, USA). Descriptive statistics were expressed in mean, standard deviation (SD), and min-max values or number and frequency. Statistical analysis for VAS values was performed using a matched paired t-test. A $p$ value of $<0.05$ was considered statistically significant.

\section{RESULTS}

Throughout the study period, a total of 49 septorhinoplasty patients were treated using this surgical technique. A total of four patients with missing followup data were excluded from the study. Finally, 45 patients were included.

The total follow-up was six months in 13 patients, 12 months in 22 patients, and 18 months in 10 patients. The mean preoperative VAS score was $7.3 \pm 1.7$. The mean postoperative VAS score was $1.6 \pm 1$.9. There was a statistically significant difference between the mean pre- and postoperative VAS scores $(\mathrm{p}<0.0001)$.

None of the patients experienced any major complication during the early or late postoperative period. However, two patients (4.4\%) had columellar indurations within the first week following surgery which resolved with antibiotic pomade. In addition, one patient $(2.2 \%)$ had septum redeviation which did not require revision surgery.

\section{DISCUSSION}

The aim of septorhinoplasty is to provide aesthetic compatibility of the nose with facial features of the patient and to correct nasal dysfunction and to prevent function disorders, if available. ${ }^{[9-13]}$ Long-term solid tip support should be established to prevent impairment of nasal tip projections and symmetry. ${ }^{[1,12]}$ Although it is stabilized, fixation can be inadequate due to damaged septal and nasal spine connections, thereby, leading to postoperative luxation-induced redeviation. ${ }^{[5]}$ In addition, insufficient support or overresection may cosmetically produce loss of tip projection, columellar retraction, and supratip depression. ${ }^{[5]}$ Danie ${ }^{[13]}$ suggested that, to fix the septum to the midline, the nasal spine should be fixed to the septum with 4.0 PDS on the other side with no deviation, by fully mobilizing the caudal septum after drilling open a hole in the anterior nasal spine.

The septopremaxillary 8 suture is one of the procedures commonly used for midline fixation of the base. Absorbable suture is passed through the base of the septum and through the nasal spine and closed intraseptally. At the same time, it is sutured at the caudal septal incision. The septum and caudal septal incision are usually closed simultaneously with two or three horizontal matrix sutures using a flat needle. ${ }^{[1]}$

Kenyon et al. ${ }^{[6]}$ described mattress sutures in patients with dislocated septum. A mattress suture on the incision side is used to fix the septum to the opened full length columellar pocket with Kenyon suture technique. An absorbable suture such as 3.0 Vicryl Rapid was used as the suture material. In another study conducted in our clinic, 71 patients with septal caudal dislocation were subjected to the septocolumellar suture technique during septoplasty (4.0 absorbable monofilament suture [Vicryl, Ethicon Inc., Somerville, NJ, USA]). No graft was used in any of the patients. No septal recurrent deviation or dislocation was reported in our patients at six and 18-month follow-up. Only two patients developed postoperative columellar indurations which resolved with antibiotic pomade. ${ }^{[14]}$ Technically, we used 
a mattress suture; however, our implementation was simpler with the ability to be applied not only in caudal deviations, but also in all patients with septal deviation.

Late absorbable or non-absorbable sutures can be used during septorhinoplasty for cartilage reshaping and suture fixation. ${ }^{[15]}$ Although Tebbetts ${ }^{[9]}$ used polypropylene or nylon sutures and, although it was reported that no suture-related complications developed in the patients who were followed for one to seven years, unexpected late-stage problems may be observed with non-absorbable sutures. ${ }^{[9,15,16]}$

Among sutures, multifilament sutures and natural sutures have a higher tissue reaction rate, compared to monofilament sutures and synthetic sutures, respectively. ${ }^{[17]}$ In an experimental study with polypropylene mesh conducted by Kama et al., ${ }^{[18]}$ polypropylene was reported to cause an inflammatory reaction with significant fibrotic formation, but showed a significantly limited foreign body reaction. Cardenas et al. ${ }^{[7]}$ reported the used of $5 / 0$ poly propylene during nasal tip surgery. Gruber ${ }^{[11]}$ reported that the use of 4/0 PDS for nasal typology produced better results. Neu, ${ }^{[8]}$ in their study, recommended the use of 5/0 nylon sutures to provide concavity of nasal tip cartilage. However, cartilage reshaping through suturing is critically important within the postoperative first two to three months, and the scar tissue that forms around the cartilage during this period supports cartilaginous fixation by the suture in soft tissue patterns. ${ }^{[9,19]}$ The presence of suture after this period reduces cartilage reshaping. Therefore, it is not necessary to use non-absorbable suture materials for cartilage reshaping. ${ }^{[19]} \mathrm{We}$ used 4.0 absorbable monofilament sutures in our patients. No case of tissue reaction or late-stage fibrosis was reported in any of our patients. Moreover, tissue elasticity did not occur at all or occurred very late in patients who were exposed to non-absorbable sutures.

One of the major supportive mechanisms of the nasal tip is the connection between the medial crura of the lower lateral cartilage and septal cartilage, whereas one of the minor support is the membranous septum. ${ }^{[13,20]}$ Since the connection between the septum and medial crura is completely cut-off in cases with transfusion incisions, the nasal tip support becomes weak resulting in de-projection of the tip. ${ }^{[21]}$ In classical septoplasty, unilateral hemitransfixion incision is performed, whereas bilateral transfixion incision is often performed in combination with intercartilaginous or intracartilaginous incision in the closed septorhinoplasty technique. ${ }^{[11,22]}$ Although transfixion incision has been considered general overall approach for many years in closed rhinoplasty cases, hemitransfixion incision has currently gained ground as the technique of choice. ${ }^{[20,23]}$ It is important to firmly secure the incision area with septocolumellar suture, when a transfixion incision is performed. ${ }^{[20]}$ We used hemitransfixion incisions in our cases. No unexpected projection loss was reported in any of our patients.

Cartilaginous grafts are very important in nasal tip surgical operations. ${ }^{[24]}$ Cartilaginous grafts have critical functions in controlling and reshaping nasal tip projection and rotation. ${ }^{[4,12,15]}$ The septal cartilage is the most suitable site for grafting due to its smooth structure and hardness. Auricular conchal cartilage is preferred under conditions where the septal cartilage cannot be used; however, a thin cartilage structure and excessive concavity of the cartilage poses as a disadvantage to the procedure. ${ }^{[24]}$ In this study, we did not include patients with grafts in our patient group to draw attention to the benefits of the suture technique.

The main goal of using intranasal tampons during septorhinoplasty is to provide stability to the cartilage and bone skeleton, prevent synechia with the lateral nasal wall, and to keep bleeding under control. ${ }^{[5]}$ Lemmens and Lemkens ${ }^{[25]}$ reported that in the transseptal technique where no packs were used, no bleeding, infection, hematoma, perforation, and no synechia was reported in 226 patients with mild pain. Although the transseptal suture technique has been reported to reduce pain and increase patient comfort, the aforementioned authors used internal Doyle nasal packs on all the patients to provide septal fixation and to prevent complications.

The main limitations of the study include the lack of a control group in which no graft was used and the lack of objective rhinomanometric values.

In conclusion, based on our study results, implementing the two-level suture technique with closed septorhinoplasty for midline fixation of the septum was successful. The tip support was preserved and symmetry was not disrupted. In our experience, patients with septal and nasal deformities, which consist of various types of minor to major deviations, have very satisfactory functional and cosmetic results in the long-term. Very favorable results can be also obtained with correction of minimal alar base asymmetries. The incision scar of open rhinoplasties where tip support is easily provided does not lead to complications which occur secondary to excessive resection performed to provide tip de-projection when implementing closed rhinoplasty techniques. Unlike many surgeons, we are convinced that absorbable suture materials used for fixation of the floor are effective and adequate and that they greatly minimize the risk of tissue reaction. 


\section{Declaration of conflicting interests}

The authors declared no conflicts of interest with respect to the authorship and/or publication of this article.

\section{Funding}

The authors received no financial support for the research and/or authorship of this article.

\section{REFERENCES}

1. Huizing EH, de Groot JAM, editors. Septal surgery. In: Basic Functional Reconstructive Nasal Surgery. New York: Thieme; 2003. p. 140-88.

2. Ridenour BD. The nasal septum. In: Cumming CW, editor. Otolaryngology Head and Neck Surgery. St. Louis: Mosby Year Book; 1998. p. 921-48.

3. Gunter JP, Rohrich RJ. Management of the deviated nose. The importance of septal reconstruction. Clin Plast Surg 1988;15:43-55.

4. Erbek S, Erbek SS. Eğri burunlarda dorsal septal deviasyonların spreader greft ile düzeltilmesi. KBB-Forum 2003;2:76-80.

5. Bloom JD, Kaplan SE, Bleier BS, Goldstein SA. Septoplasty complications: avoidance and management. Otolaryngol Clin North Am 2009;42:463-81.

6. Kenyon GS, Kalan A, Jones NS. Columelloplasty: a new suture technique to correct caudal septal cartilage dislocation. Clin Otolaryngol Allied Sci 2002;27:188-91.

7. Cardenas JC, Carvajal J, Ruiz A. Securing nasal tip rotation through suspension suture technique. Plast Reconstr Surg 2007;120:1741-2.

8. Neu BR. Suture correction of nasal tip cartilage concavities. Plast Reconstr Surg 1996;98:971-9.

9. Tebbetts JB. Shaping and positioning the nasal tip without structural disruption: a new, systematic approach. Plast Reconstr Surg 1994;94:61-77.

10. Khodaei I, Palma P. The judicious use of grafts in endonasal septorhinoplasty. B-ENT. 2010;6:77-87.

11. Gruber RP. Suture techniques in rhinoplasty by use of the endonasal (closed) approach. Aesthet Surg J 1998;18:99-103.
12. Akkus AM, Eryilmaz E, Guneren E. Comparison of the effects of columellar strut and septal extension grafts for tip support in rhinoplasty. Aesthetic Plast Surg 2013;37:66673.

13. Daniel RK, editor. Rhinoplasty. An Atlas of Surgical Techniques. New York: Springer-Verlag; 2002. p.163-225.

14. Demirbilek N, Evren C, Elbistanlı MS, Altun U, Günay SS. Two-level septocolumellar suture technique for correction of septal caudal dislocation. Braz J Otorhinolaryngol 2016;82:403-7.

15. Gruber RP, Nahai F, Bogdan MA, Friedman GD. Changing the convexity and concavity of nasal cartilages and cartilage grafts with horizontal mattress sutures: part II. Clinical results. Plast Reconstr Surg 2005;115:595-606.

16. Çağııı CA, Erkan AN, Yılmazer C, Özer C, Çakmak Ö. Septorinoplasti sonrası dikişe bağlı geç dönem burun ucu enfeksiyonu. KBB ve BBC Dergisi 2007;15:31-6.

17. Altınyazar HC, Koca R. Dermatolojik cerrahide sik kullanilan suture materyalleri. Dermatose 2004;3:13-7.

18. Kama NA, Coskun T, Yavuz H, Doganay M, Reis E, Akat AZ. Autologous skin graft, human dura mater and polypropylene mesh for the repair of ventral abdominal hernias: an experimental study. Eur J Surg 1999;165:1080-5.

19. DeMars RV, Schenden MJ, Manders EK, Graham WP. The permanence of otoplasty in the rabbit ear: a comparison of techniques. Ann Plast Surg 1984;13:195-8.

20. Huizing EH, de Groot JAM, editors. Incisions and approaches. In: Basic Functional Recontsructive Nasal Surgery. New York: Georg Thieme Verlag; 2003. p. 124-38.

21. Solomon P, Rival R, Mabini A, Boyd J. Transfixion incision as an initial technique in nasal tip deprojection. Can J Plast Surg 2008;16:224-7.

22. Tezel E, Numanoğlu A. Septocolumellar suture in closed rhinoplasty. Ann Plast Surg 2007;59:268-72.

23. Heppt W, Gubisch W. Septal surgery in rhinoplasty. Facial Plast Surg 2011;27:167-78.

24. Zijlker TD, Vuyk H. Cartilage grafts for the nasal tip. Clin Otolaryngol Allied Sci 1993;18:446-58.

25. Lemmens W, Lemkens P. Septal suturing following nasal septoplasty, a valid alternative for nasal packing? Acta Otorhinolaryngol Belg 2001;55:215-21. 